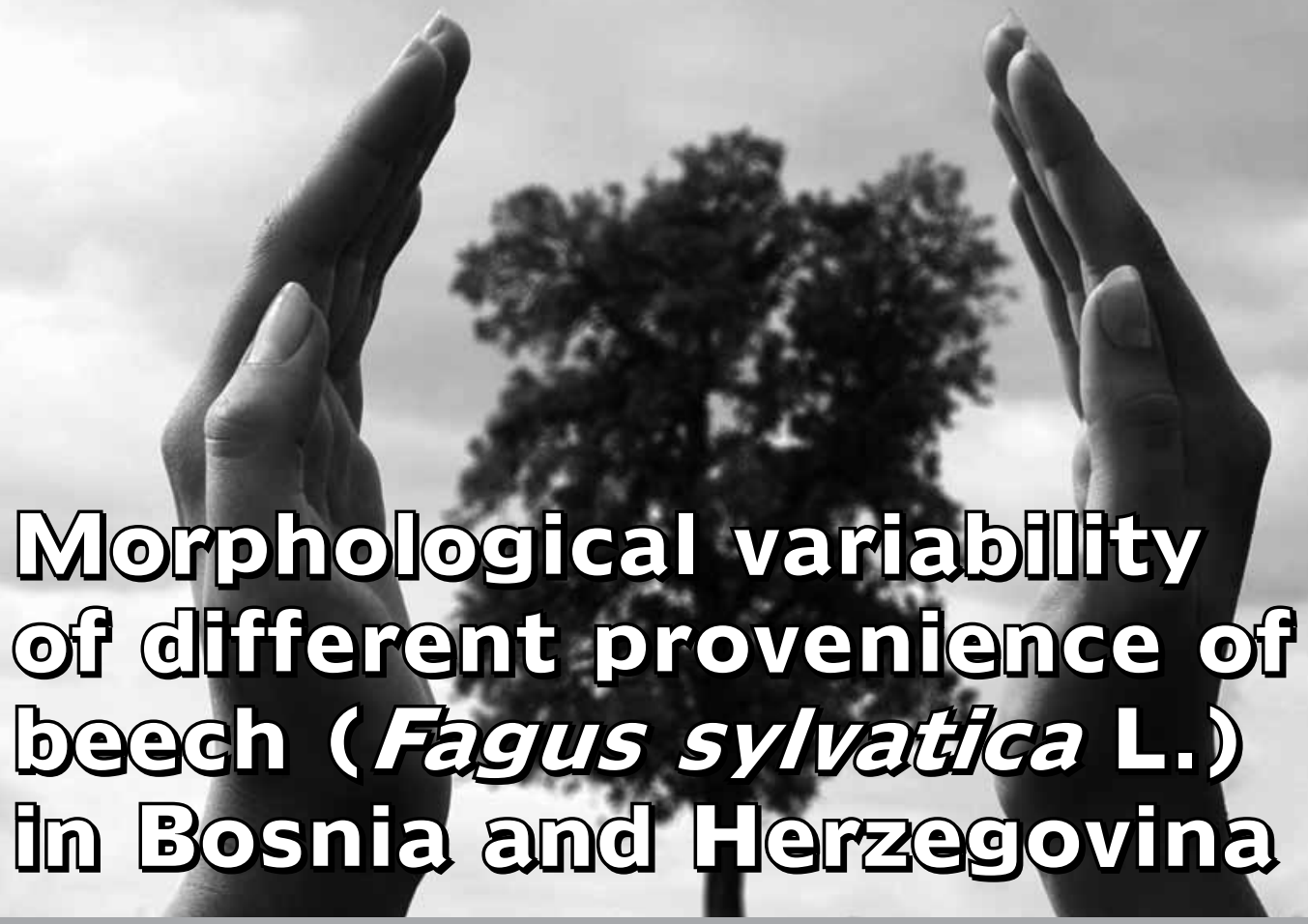

Faruk Mekić

Faculty of Forestry, Sarajevo, Zagrebačka 20, 71000 Sarajevo, Bosnia and Herzegovina mekicf@bih.net.ba

\section{Ćemal Višnjić}

Faculty of Forestry, Sarajevo, Zagrebačka 20, 71000 Sarajevo, Bosnia and Herzegovina
Sead Ivojević

Faculty of Forestry, Sarajevo, Zagrebačka 20, 71000 Sarajevo, Bosnia and Herzegovina

\section{Recived 13. 03. 2010.}

\section{Background and purpose:}

In this paper was researched the morphological variability of seed and one-year seedlings of beech of different proveniences from the major part of its natural dispersing in Bosnia and Herzegovina (from the Bužim, Bugojno, Banja Luka, Bosansko Grahovo, Posušje and Olovo).

\section{Material and methods:}

There were researched: length $(\mathrm{I})$, width $(\mathrm{w})$ and mass $(m)$ of the seed, of the deducted parameters was calculated the coefficient of the shape of seed which was presented by relation of length and width of the seed $\left(C_{1 / w}\right)$. On the seedlings were measured the diameter at the neck of the root $\left(D_{n r}\right)$ and height of the seedlings $(H)$.

\section{Results and Conclusion:}

The largest seed was identified in the provenience Banja Luka $(I=16.17 \mathrm{~mm}, w=8.15 \mathrm{~mm}$, $\mathrm{m}=0.275 \mathrm{~g})$, while the smallest was in provenience Bosansko Grahovo $(I=15.47 \mathrm{~mm}, w=7.22$ $\mathrm{mm}, \mathrm{m}=0.143 \mathrm{~g}$ ). Mean values of the mentioned indicators of seed for all proveniences from Bosnia and Herzegovina were: mean length of seeds $15.65 \mathrm{~mm}$, mean width of seeds $7.91 \mathrm{~mm}$, average mass of the seeds $0.218 \mathrm{~g}$.
Coefficient of the shape of seeds $\left(C_{1 / w}\right)$ had the mean value of 1.99. Seedlings of beech were the most developed in the provenience Olovo $\left(D_{\mathrm{nr}}=3.50 \mathrm{~mm}, \mathrm{H}=12.49 \mathrm{~cm}\right)$, and the smallest dimensions had the seedlings form the provenience near Posušje $\left(D_{n r}=2.83 \mathrm{~mm}, \mathrm{H}=9.38 \mathrm{~cm}\right)$. The mean diameter of the seedlings of beech for all proveniences was $D_{n r}=3.16 \mathrm{~mm}$, mean height $\mathrm{H}=11.54 \mathrm{~cm}$. Results of the conducted researches point to expressed morphological variability of seed and seedlings of the researched proveniences of "Bosnian" beech which points to the needs for established horizontal and vertical seed regions of this species in Bosnia and Herzegovina.

\section{Key words:}

beech, seed, seedlings, proveniences, morphological variability

\section{INTRODUCTION}

Beech (Fagus sylvatica L.) is a significant tree species in the area of Central and South Europe, where it helds a dominant place in terms of surface, economic and other values (1). In the area of South-East Europe, it participates with 12 million ha in vegetation cover. In Serbia it covers about 1.25 million ha or $50 \%$ of total surface under forests (2). In Croatia, beech is not 
only the most disperse species (744-796 ha), but it is also the first per its share in timber stock. In timber reserves of Republic Croatia, beech participates with about $36 \%$ (3). The beech also has almost the same importance in Bosnia and Herzegovina where its share in timber stock is about $47 \%$ of total timber mass, or $74 \%$ mass of deciduous trees, with the total surface of high beech forests of 347-310 ha and with average reserve of $204.2 \mathrm{~m}^{3} / \mathrm{ha}$ (4). This illustrates the importance of beech as the species from both the economic and ecological aspect. Beech is almost exclusively renewed in natural way, which is the basic assumption of its biological diversity, production ability and stability (1). In Bosnia and Herzegovina, however, the largest complexes of high beech forests were turned into stamp forests and lower degraded phases: brush-woods and scrubs, by unorganized and uncontrolled cutting; Also natural regeneration was difficult $(5,6)$. To make afforestation successful, it is necessary to obtain good planting material, especially on surfaces whith advanced level of degradation, and where the status of stand is significantly changed. Until present, little has been done on production of planting material and growing of forest cultures of beech $(7,6)$. By the end of 1950s, research on variability of beech indicated that it belongs to the group of less-diverse tree species. It resulted in the initiative to intensify the research on genetic variability of beech conducted throughout Europe, encompassing over 800 populations of beech (1).

These researches have great significance regarding enriching the beech, especially in selection of adequate proveniences for planting in particular habitats. That significance is increased in regard of seedproduction and extraction of seed areas, with a goal to select more superior proveniences with favourable characteristics and to preserve genetic resources of the beech. In the sense of targeted selection seed material, Gradečki et al., (8) conducted the research of some morphological and physiological characteristics of seed of beech in Croatia, and they have identified significant differences in the size of morphological indicators of seed compared to the origin. For the production of quality planting material, apart from the favourable conditions provided in nurseries, it is necessary to have good quality of seed material.
This paper describes the laboratory researches on morphological variability and quality indicators of seed of different proveniences of beech and field researches of the growth of saplings in the first year after the planting and the impact of morphological indicators of seed to the quality of saplings in the first year of growth.

\section{MATERIAL AND METHODS}

The seed of beech was collected in late September and early October 2007 at six localities in Bosnia and Herzegovina (1. Bužim, 2. Bugojno, 3. Banja Luka, 4. Bosansko Grahovo, 5. Posušje and 6. Olovo). Selection of localities was conducted in a way to encompass as many ecological-vegetation areas in Bosnia and Herzegovina as possible and from the stands of beech from different altitudes, but with as even as possible structural characteristics: the level of composition, development phases of the stands, and appearance. The basic indicators of the area and the localities for collection of seeds are given in Table 1 and presented in the Map 1 (according Fukarek 1970).

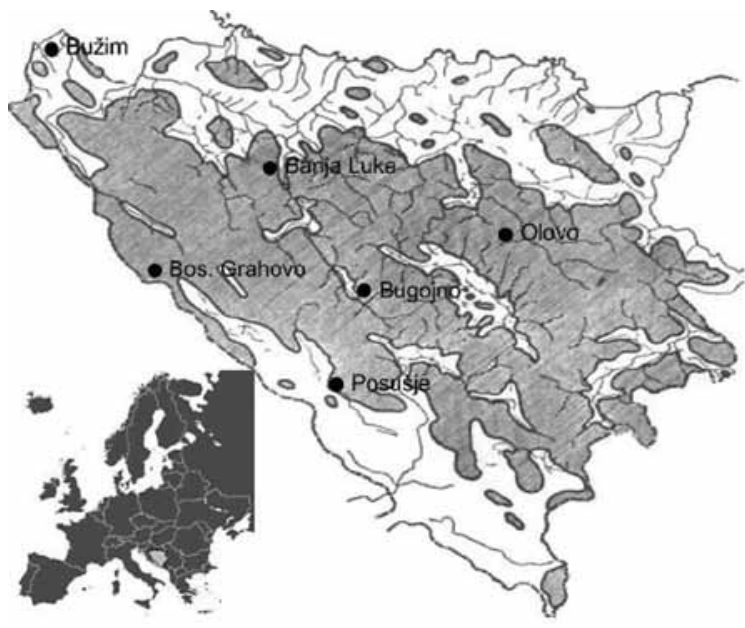

Map 1

Localities of researched proveniences of beech within its natural areal in Bosnia and Herzegovina (according Fukarek 1970)

Table 1

Localities of particular proveniences with geographic coordinates

\begin{tabular}{|r|l|l|l|l|}
\hline No. & Proveniences & Locality & Altititude $(\mathrm{m})$ & Geog. coord. \\
\hline 1. & Bužim & "Glinica" & $300-350$ & $\mathrm{~N}=45^{\circ} 05^{\prime}, \mathrm{E}=16^{\circ} 05^{\prime}$ \\
\hline 2. & Bugojno & "Skrta-Nišan & $600-700$ & $\mathrm{~N}=43^{\circ} 50^{\prime}, \mathrm{E}=17^{\circ} 25^{\prime}$ \\
\hline 3. & Banja Luka & "Osmača-Tisovac" & $630-780$ & $\mathrm{~N}=44^{\circ} 39^{\prime}, \mathrm{E}=17^{\circ} 10^{\prime}$ \\
\hline 4. & Bos. Grahovo & "Peulje" & $830-850$ & $\mathrm{~N}=42^{\circ} 40^{\prime}, \mathrm{E}=18^{\circ} 40^{\prime}$ \\
\hline 5. & Posušje & "Bosiljna" & $860-950$ & $\mathrm{~N}=43^{\circ} 28^{\prime}, \mathrm{E}=17^{\circ} 20^{\prime}$ \\
\hline 6. & Olovo & "Patkovac" & $950-1050$ & $\mathrm{~N}=44^{\circ} 10^{\prime}, \mathrm{E}=18^{\circ} 30^{\prime}$ \\
\hline
\end{tabular}


Of the total quantity of collected seed, samples were taken from not les than 1,000 grains of each provenience. Measuring of length (I), width (w) and mass of seed $(m)$ were conducted on these samples (Fig 1). The length and width of seeds were measured by digital calipers with a precision of $0.01 \mathrm{~mm}$ and the mass of seed was identified by digital scale with a precision of down to 0.01 gram.

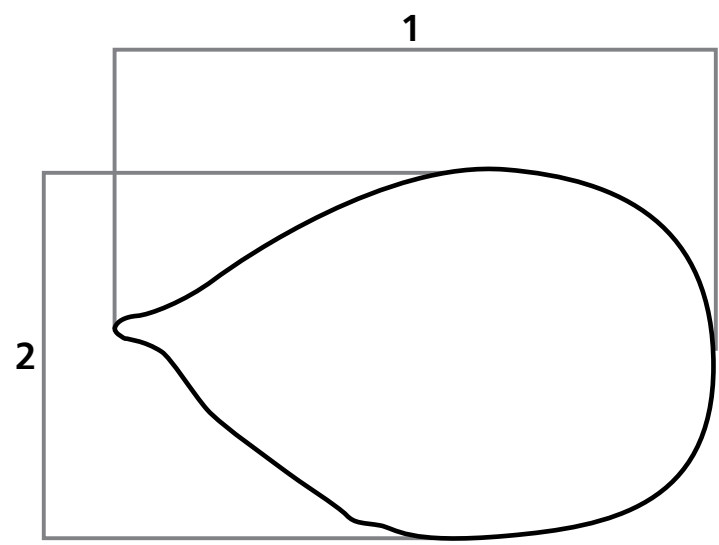

Figure 1

Measured parameters on seed

(1 - length of seed, 2 - width of seed)

The percentage of humidity was identified by method of drying chamber at $130{ }^{\circ} \mathrm{C}$, the seed was dried for 1 hour and after that it was measured on scale. Absolute mass of seed was identified on four tests/ trials with 100 grains of seed each, taken from the component of pure seed. By calculation of mean value by the method of ISTA, the mass of 1,000 grains of seed was identified. Vitality of seed was identified by indigo-carmine method (seed was previously submerged into water for $24 \mathrm{~h}$, and than embryos were explanted, which were treated in 0.05 $\%$ solution of indigo-carmine in the duration of $2 \mathrm{~h}$ at $30{ }^{\circ} \mathrm{C}$ in thermostat, in dark).

The seed of beech was stratified by cold-wet procedure in silicate sand, where it stayed for five weeks. After that, in mid-April 2008, the planting in the nursery "Sedrenik" was conducted. The seed was planted in the quantity of $180-200 \mathrm{gr} / \mathrm{m}^{2}$ seedbeds, or $800-1,000 \mathrm{seeds} / \mathrm{m}^{2}$. Similar quantities in their experiments were used by some other authors $(7,9$, $10)$. After the planting, the seed was covered by the layer of silicate sand of thickness of $2-2.5 \mathrm{~cm}$.

At the end of vegetation period the measurement was conducting of morphological indicators of saplings, diameter at the neck or the root and the height of seedlings. Diameters at the neck of the root were measured by digital calipers with the precision of 0.01 $\mathrm{mm}$ and the height of seedlings by ruler at precision of $1 \mathrm{~mm}$. Data obtained by measurement of individual morphological parameters of seed and saplings were entered into statistical software: "WINSTAT" and "STATISTICA" where the statistical processing of it was conducted. The analysis of variance and identified dependence of individual measured parameters were conducted by establishing correlation analysis as well as cluster analyses.

\section{RESULTS OF RESEARCH}

\section{Morphological indicators of seed of beech}

\section{Mean length of the seed}

The length of the seed as morphological indicator was measured, for each provenience, at the sample of at least 1,000 seeds. Figure 2 shows mean values and variation of the length of seeds within particular proveniences.

Regarding the mean length of seeds, the provenience Bužim had the highest, both mean and maximal values, while the provenience Posušje had the lowest values of this characteristic. Then, the analysis of variance was conducted, the results of which were presented in Table 2 .

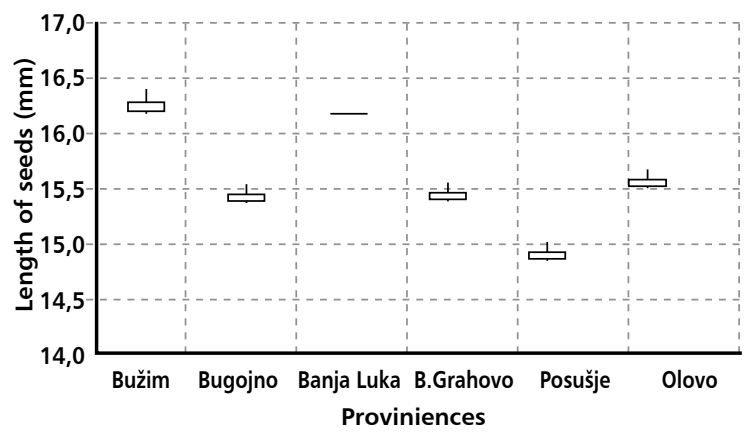

\section{Figure 2}

Mean length of seeds $(\mathrm{mm})$ per proveniences

By the analysis of variance, statistically significant differences have been identified at the probability of $95 \%$ with small coefficient of variability for the researched indicator within proveniences. Proveniences are distributed in 5 Duncan test groups. Provenience from Bužim has the largest average lengths of seeds $(16.29 \mathrm{~mm})$ and statistically it differs from all other proveniences, while provenience Posušje has the smallest average length of seeds of $14.93 \mathrm{~mm}$ and by that indicator it is significantly different from other proveniences. Proveniences Bosansko Grahovo and Bugojno belong to the same Duncan test group and per size of mean length of seed are in the middle. Although the difference between the largest and smallest average length of seed is small and it is $1.36 \mathrm{~mm}$, the statistical differences between proveniences appeared due to small variation of the research characteristics within proveniences. Therefore the average coefficient of 


\section{Table 2}

Analysis of variance of the length of seeds per proveniences (St. dev. = standard deviation, CV = coefficient of variability)

\begin{tabular}{|c|c|c|c|c|c|c|}
\hline Rang & Proveniences & $\mathbf{N}$ & Mean $(\mathrm{mm})$ & St. dev. & CV (\%) & Duncan test - grouping \\
\hline 1. & Bužim & 1005 & 16,29 & $\pm 0,099$ & 9,84 & a \\
\hline 2. & Banja Luka & 1000 & 16,17 & $\pm 0,004$ & 7,40 & b \\
\hline 3. & Olovo & 1005 & 15,57 & $\pm 0,061$ & 6,28 & c \\
\hline 4. & Bos. Grahovo & 1000 & 15,47 & $\pm 0,066$ & 6,93 & d \\
\hline 5. & Bugojno & 1000 & 15,45 & $\pm 0,063$ & 6,58 & d \\
\hline 6. & Posušje & 1000 & 14,93 & $\pm 0,057$ & 6,13 & e \\
\hline \multicolumn{2}{|c|}{ Sum/mean } & 6010 & 15,65 & $\pm 0,058$ & 7,19 & - \\
\hline
\end{tabular}

variability was 7.19. The average length of seed for all proveniences of Bosnian beech was $15.65 \mathrm{~mm}$.

\section{Mean width of seeds}

The width of seeds is the characteristic which was measured in the same samples like for length, and the results are shown in the Figure 3.

Maximal mean value of the width of seeds was identified at the provenience Bugojno, which is followed by the provenience near Olovo, while the lowest mean value was recorded at provenience from the area of Bosansko Grahovo.

Also, deviations from the mean value are very small, and it is the same like in the case of length of seeds, which points to the small within-the-proveniences variability considering this characteristic. Results of the analysis of variance of the width of seed characteristics are presented in

Table 3.

By the analysis of variance, at the probability of 95 $\%$, statistically significant differences in the width of seed of beech were identified between each of the observed proveniences.

Proveniences were designated to 6 Duncan test groups. Mean values vary in the interval from $7.22 \mathrm{~mm}$ to $8.36 \mathrm{~mm}$, with rather small variation coefficients.

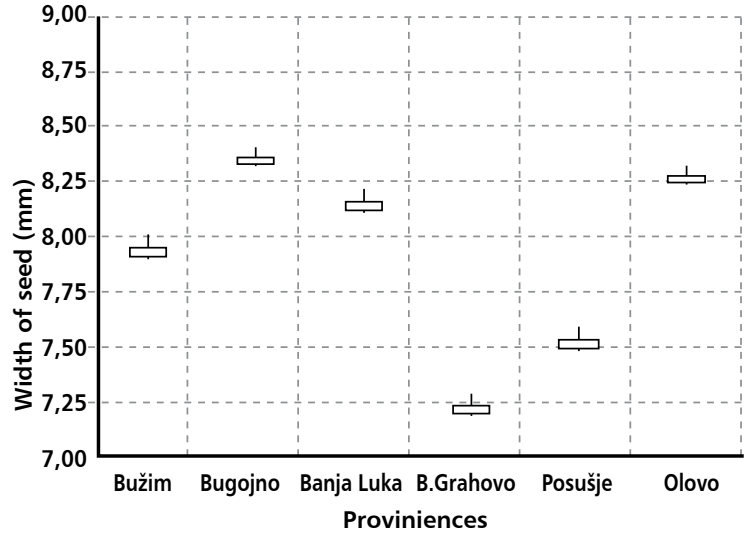

Figure 3

Width of seed $(\mathrm{mm})$ per proveniences

The larges mean value of the width of seed was shown in the provenience of Bugojno which is statistically and significantly different from other proveniences, while the smallest width of seed was at the provenience of Bosansko Grahovo which belongs to the last Duncan group. The average value of the width of seed for all proveniences is $7.91 \mathrm{~mm}$.

\section{Table 3}

Analysis of variance of width of seed per proveniences (St. dev. = standard deviation, CV = coefficient of variability)

\begin{tabular}{|c|c|c|c|c|c|c|}
\hline Rang & Proveniences & $\mathbf{N}$ & Mean (mm) & St. dev. & CV (\%) & Duncan test - grouping \\
\hline 1. & Bugojno & 1000 & 8,36 & $\pm 0,04$ & 7,71 & a \\
\hline 2. & Olovo & 1005 & 8,27 & $\pm 0,04$ & 8,49 & b \\
\hline 3. & Banja Luka & 1000 & 8,15 & $\pm 0,05$ & 9,31 & c \\
\hline 4. & Bužim & 1005 & 7,95 & $\pm 0,06$ & 11,54 & d \\
\hline 5. & Posušje & 1000 & 7,52 & $\pm 0,04$ & 7,79 & e \\
\hline 6. & Bos. Grahovo & 1000 & 7,22 & $\pm 0,04$ & 7,99 & $f$ \\
\hline \multicolumn{2}{|c|}{ Sum/mean } & 6010 & 7,91 & $\pm 0,04$ & 8,81 & - \\
\hline
\end{tabular}




\section{Coefficient of the shape of seeds $\left(C_{/ / w}\right)$}

As the indicators of the shape of seed, the relation between length (I) and width ( $w$ ) of the seed is very interesting. For every seed per proveniences, this relation was calculated in the form of coefficient $C_{1 / w^{\prime}}$ the results of which were presented in Figure 4 and Table 4.

It is apparent from the table that there are statistically significant differences in the coefficient of the shape of seed between researched proveniences. Based

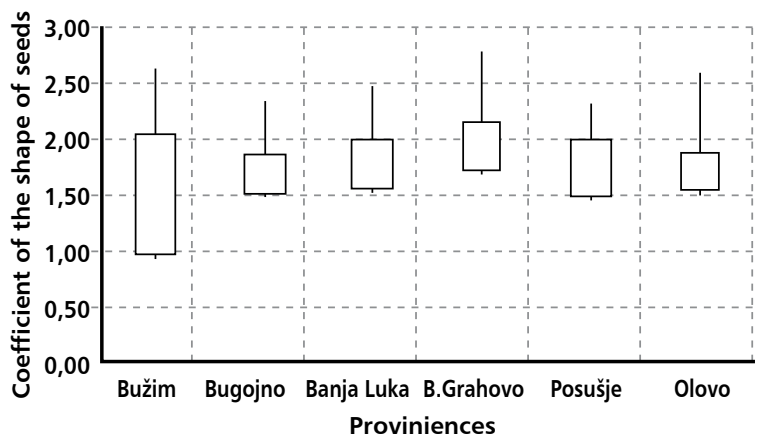

Figure 4

Coefficient of the shape of seeds $(\mathrm{Cl} / \mathrm{w})$ per proveniences

\section{Table 4}

Mean values of the coefficient of seeds Cl/w, per proveniences (St. dev. = standard deviation,

$C V=$ coefficient of variability)

\begin{tabular}{|c|c|c|c|c|c|c|}
\hline Rang & Provenijences & $\mathrm{N}$ & $\begin{array}{c}\text { Mean } \\
(\mathrm{mm})\end{array}$ & St.dev. & CV (\%) & Duncan test - grouping \\
\hline 1. & Olovo & 93 & 3,50 & $\pm 0,235$ & 32,53 & a \\
\hline 2. & Bužim & 93 & 3,33 & $\pm 0,146$ & 21,32 & a \\
\hline 3. & Bugojno & 92 & 3,08 & $\pm 0,167$ & 26,24 & b \\
\hline 4. & Banja Luka & 91 & 3,04 & $\pm 0,184$ & 29,16 & b \\
\hline 5. & Posušje & 83 & 2,83 & $\pm 0,126$ & 20,46 & b \\
\hline \multicolumn{2}{|c|}{ Sum/mean } & 452 & 3,16 & $\pm 0,172$ & 25,94 & - \\
\hline
\end{tabular}

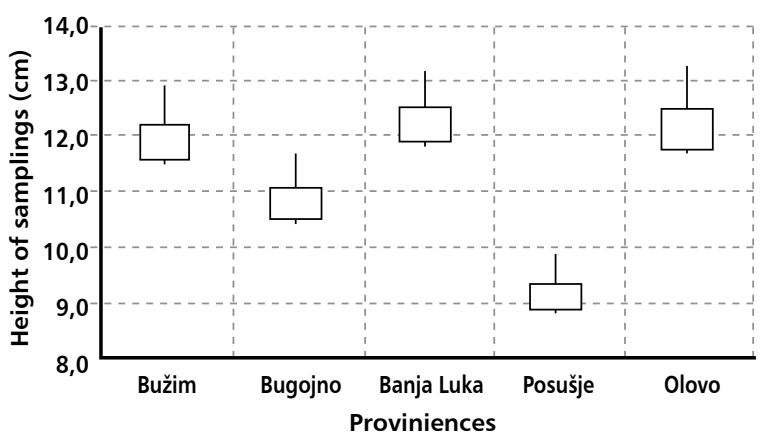

Figure 6

Height of saplings $(\mathrm{cm})$ on the results of the analysis of variance, 5 Duncan groups were designated.

\section{Morphological indicators of saplings}

\section{Diameter at the root neck}

Researches on morphological indicators of beech saplings were conducted at five proveniences of beech.

Provenience Bosansko Grahovo in these researches was not represented due to the lack of saplings. Seed of this provenience was not sufficiently germinated and there was no sufficient number of saplings to conduct measurements on it.The identified mean values of the diameter of root neck of saplings of different proveniences of beech are presented in Figure 5 .

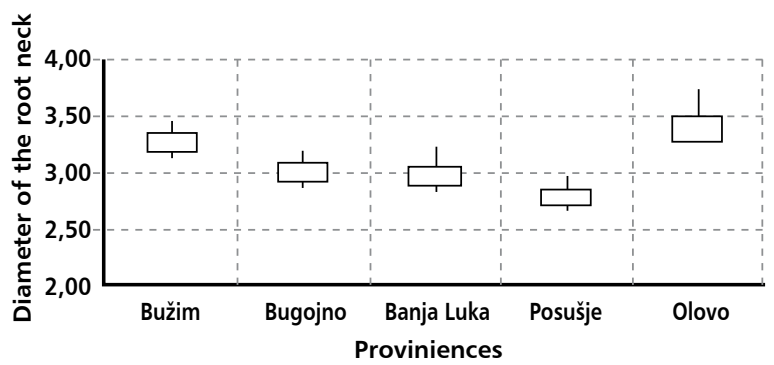

Figure 5

Diameter at the root neck $(\mathrm{mm})$ per proveniences
The highest mean values of diameter at the root neck were recorded at saplings from the provenience Olovo. The lowest mean diameter at the root neck was shown in the provenience Posušje.

In order to identify statistically important differences in the size of diameter at the root neck the analysis of variance was conducted with Duncan test. Results of testing are shown in the Table 5.

By the analysis of variance of the tested characteristics, with the probability of $95 \%$, two Duncan test groups were separated, which are significantly different. In the first group, with higher mean diameter at the root neck, the proveniences are: Olovo and Bužim and in second: Bugojno, Banja Luka, and Posušje. 
Table 5

Analysis of the value of diameter at the root neck of saplings per proveniences

(St. dev. = standard deviation, $C V=$ coefficient of variability)

\begin{tabular}{|r|c|c|c|c|c|c|}
\hline Rang & Provenijences & N & $\begin{array}{c}\text { Mean } \\
(\mathrm{mm})\end{array}$ & St.dev. & CV (\%) & Duncan test - grouping \\
\hline 1. & Olovo & 93 & 3,50 & $\pm 0,235$ & 32,53 & a \\
\hline 2. & Bužim & 93 & 3,33 & $\pm 0,146$ & 21,32 & a \\
\hline 3. & Bugojno & 92 & 3,08 & $\pm 0,167$ & 26,24 & b \\
\hline 4. & Banja Luka & 91 & 3,04 & $\pm 0,184$ & 29,16 & b \\
\hline 5. & Posušje & 83 & 2,83 & $\pm 0,126$ & 20,46 & b \\
\hline \multicolumn{2}{|r|}{ Sum/mean } & 452 & 3,16 & $\pm 0,172$ & 25,94 & - \\
\hline
\end{tabular}

The highest variation coefficient of the measured characteristic was shown in the provenience Olovo.

\section{Height of saplings}

Mean height of saplings of different proveniences of beech was shown in the Figure 6 . The highest mean height of saplings was identified at the provenience Banja Luka $(12.51 \mathrm{~cm})$ and the lowest at the provenience Posušje $(9.38 \mathrm{~cm})$.

Results of the analysis of variance are shown in the Table 6. By testing the significant differences between proveniences in reference to the mean height of saplings, it was possible to separate three Duncan groups. In first, with highest values of mean height, the following proveniences were separated: Banja Luka, Olovo and Bužim, in second Bugojno and in third with the lowest mean height, the provenience Posušje.

The same situatin is with the diameter at the root neck, where the highest variations of height of saplings was recorded at the provenience of Olovo $(\mathrm{CV}=29.65)$.

\section{DISCUSSION AND CONCLUSIONS}

Results of the researches conducted on seed and saplings of beech in its natural habitat in Bosnia and Herzegovina confirm wide morphological variability of this species. If we consider the length of seed as morphological indicator of its variability, we can conclude that the within-the-provenience variability is very small, while the analysis of variance identified that the majority of proveniences are mutually statistically different.

Therefore, we have identified very narrow amplitude $(1.36 \mathrm{~mm})$ of this indicator where the lowest value is on the beech from Posušje (14.93), and the highest is in the provenience Bužim (16.29 mm). These values do not deviate in any provenience significantly from the average in the Balkans region (11).

The researches on the morphology of seeds were also conducted by other researchers in neighboring countries. The obtained values in such researches were expected and they range within similar relations as our results. Absolute value of mean values for all proveniences is $15.65 \mathrm{~mm}$, while (8) for proveniences of the Republic of Croatia give the mean length of seed of $14.89 \mathrm{~mm}$.

This data surely confirms the morphological diversity of beech in rather small area.

In his book, Stilinović (11) says that the average length of beech acorn of Mezian beech in literature sources was designated in the amount of average of $16 \mathrm{~mm}$ (it ranges from 14-19 $\mathrm{mm}$ ).

On the other hand, the group of researchers (12) have shown significant variability of this indicator depending on the provenience of seed, where the

Table 6

Analysis of the variance of height of saplings per proveniences

(St. dev. = standard deviation, CV = coefficient of variability)

\begin{tabular}{|c|c|c|c|c|c|c|}
\hline Rang & Provenijences & N & Mean $(\mathrm{cm})$ & St. dev. & CV (\%) & Duncan test - grouping \\
\hline 1. & Banja Luka & 91 & 12,51 & $\pm 0,675$ & 25,91 & a \\
\hline 2. & Olovo & 93 & 12,49 & $\pm 0,763$ & 29,65 & a \\
\hline 3. & Bužim & 93 & 12,24 & $\pm 0,686$ & 27,20 & a \\
\hline 4. & Bugojno & 92 & 11,09 & $\pm 0,603$ & 26,23 & b \\
\hline 5. & Posušje & 83 & 9,38 & $\pm 0,501$ & 24,48 & c \\
\hline \multicolumn{2}{|c|}{ Sum/mean } & 452 & 11,54 & $\pm 0,646$ & 26,69 & - \\
\hline
\end{tabular}




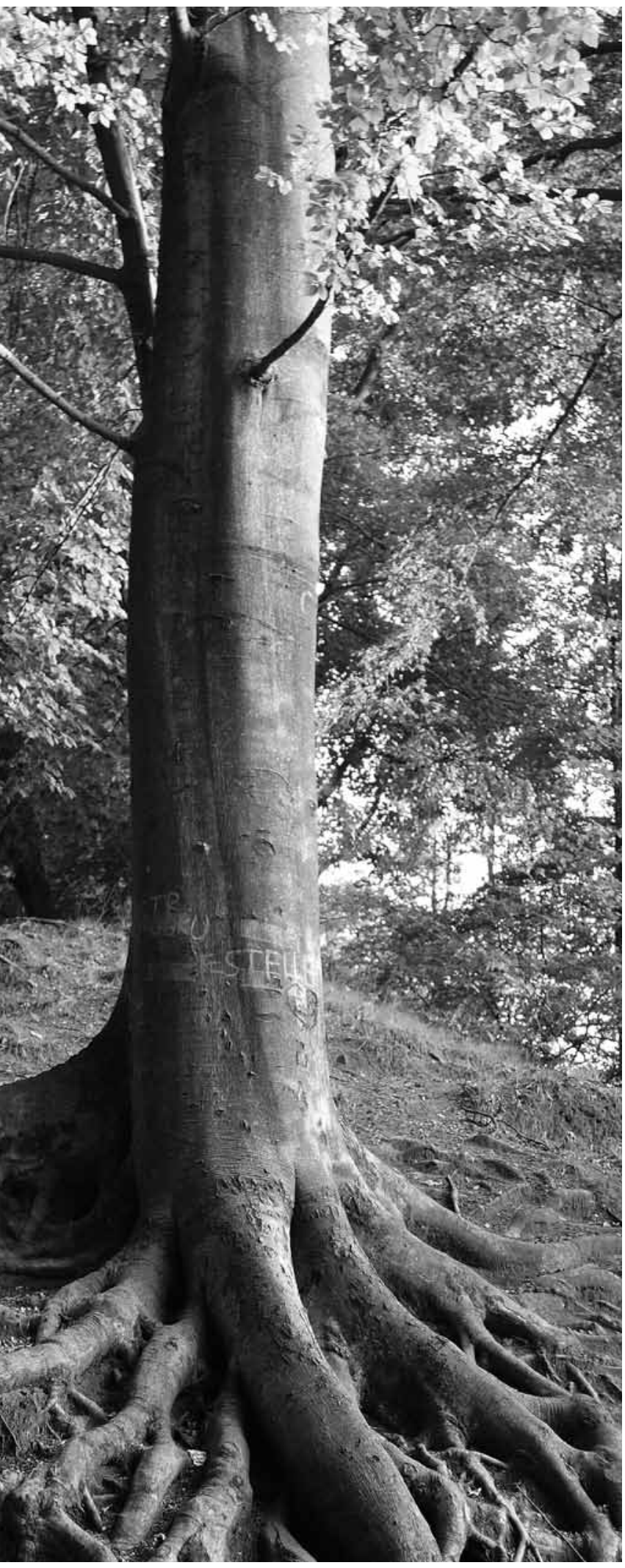

measured length of beech acorn was 15.38-17.05 $\mathrm{mm}$. The last mentioned researchers have clearly defined that there exists the directly proportional correlative connection between altitude and the length of beech acorn.

Similar tendencies were also recorded in less expressed form in our researches.

Looking at the obtained results for the width of seed, we can conclude that the variability within proveniences is even lower than in the characteristics for the length of seed, and the within-the-provenience variability is higher.

According to the analysis of variance, every provenience belongs to separate group which is statistically significantly different from the other. Mean value of the width of seed for the observed proveniences which was obtained by research is 7.91 $\mathrm{mm}$ and it ranges in the amplitude from $1.14 \mathrm{~mm}$ (Bosansko Grahovo $7.22 \mathrm{~mm}$, Bugojno $8.36 \mathrm{~mm}$ ). Researches of this indicators conducted by Gradečki, et al., (8) show slightly higher values $(9.53 \mathrm{~mm})$ for the area of Croatia.

Seeds of beech from the area of Bosanko Grahovo are two times longer than wider; while the seeds from area of Bugojno have a bigger "belly". Variation coefficient in this indicator was the lowest, while the highest variability was recorded at the mass of seed. Reasons for that have to be found in the fact that the deducted coefficients are under higher genetic control than the measured indicators.

According to Reyment (13) it is considered that these characteristics, which describe the shape, show much, better the filogenetic and genetic relations between organisms (14).

According to the correlation analysis, dependences of length and width of seed were identified, where the correlation coefficient is 0.545 while between the length and mass is 0.456 and between width and mass is 0.608 .

The obtained results can be explained by fact that every tree species has particular form of seed which is genetically conditioned and for sure some deviations may occur, but in the majority of cases it is approximately permanent relation of the length and width of the seed.

Mass of the seed, above the dimensions in great extent depends on the percentage of humidity in the seed, so than the impact of the dimensions is rather small.

Absolute mass (weight of 1,000 seeds) ranges in the interval from $143.2 \mathrm{~g}$ (Bosansko Grahovo) to $274.8 \mathrm{~g}$ (Banja Luka). Almost by $100 \%$ is higher the number of seeds in one kilogram if compared between the largest and the smallest seed (number of seeds from $3,700-7,000)$. Researches conducted in Serbia show smaller differences (12) and they range from 241.14 up to $336.54 \mathrm{~g}$.

Similar results were also given in the literature (15) where the average values recorded $250 \mathrm{~g}$. According to the last mentioned sources, the number of seeds is 
$4,000 \mathrm{pcs} / 1 \mathrm{~kg}$, while in Serbia for mezian beech the number of seeds in one $\mathrm{kg}$ ranges from 3,000-4,150 grains.

In order to have a complete picture of the usable value of the seed, it would also be necessary to identify some of the internal indicators.

In the first place it is related to germination capacity of seed. Since this is the tree species which is passing trough harder and longer process of germination, we have chosen to identify the vitality by one of the most common methods (Indigo-carmine) and we have identified that it has a very wide range (from 49$91 \%)$, which points to expressed inter-provenience variability.

Except for the above given indicators within these researches we have measured the height of the seedling and the diameter at the neck of the root of the saplings of beech.

Speaking about the diameter at the neck of the root, it is visible that this indicator does not have the strength for identification of inter-provenience variability, since its measuring was conducted on plants which were planted or were not cleared from substrate.

This value shows that after the measurement of the diameter, it is necessary in average about 90 plants per provenience to obtain the value of amplitude of $0.67 \mathrm{~mm}$ between the "thickest" (2.83 mm-Posušje) and the "thinnest" (3.50 mm-Olovo).

At the end, based on the presented, we could state that there is hardly any difference between mean diameters of the proveniences. One more reliable parameter that gives better guidelines for identification of significant differences between proveniences is the indicator of height of saplings (one-year plants). After measurements of 90 plants per provenience, we have identified that the average value for "Bosnian" beech is $11.54 \mathrm{~cm}$, and the amplitude between the highest $(12.51 \mathrm{~cm}$-Banja Luka) and the shortest provenience (9.38 cm-Posušje) is $3.14 \mathrm{~cm}$.

The highest mean values of the slimness level (relation $H / D)$ were identified in saplings from the area of Banja Luka, and the lowest values at saplings of the provenience from the area of Posušje. These values are really good indicators for correct selection of proper provenience for particular habitat.

The correlation analysis was conducted on the data obtained by measurements of the researched parameters, however, there was no significant dependence between observed parameters of seed and growth of saplings, e.g. largeness of the seed does not correlate with altitude and diameter of saplings.

In order to assess the genetic distance between analyzed proveniences based on very modest indicators, yet a large number of measurements (over 15.000), the cluster analysis was conducted. Dendrogram of cluster-analyses is showing that proveniences from Posušje and Bosansko Grahovo

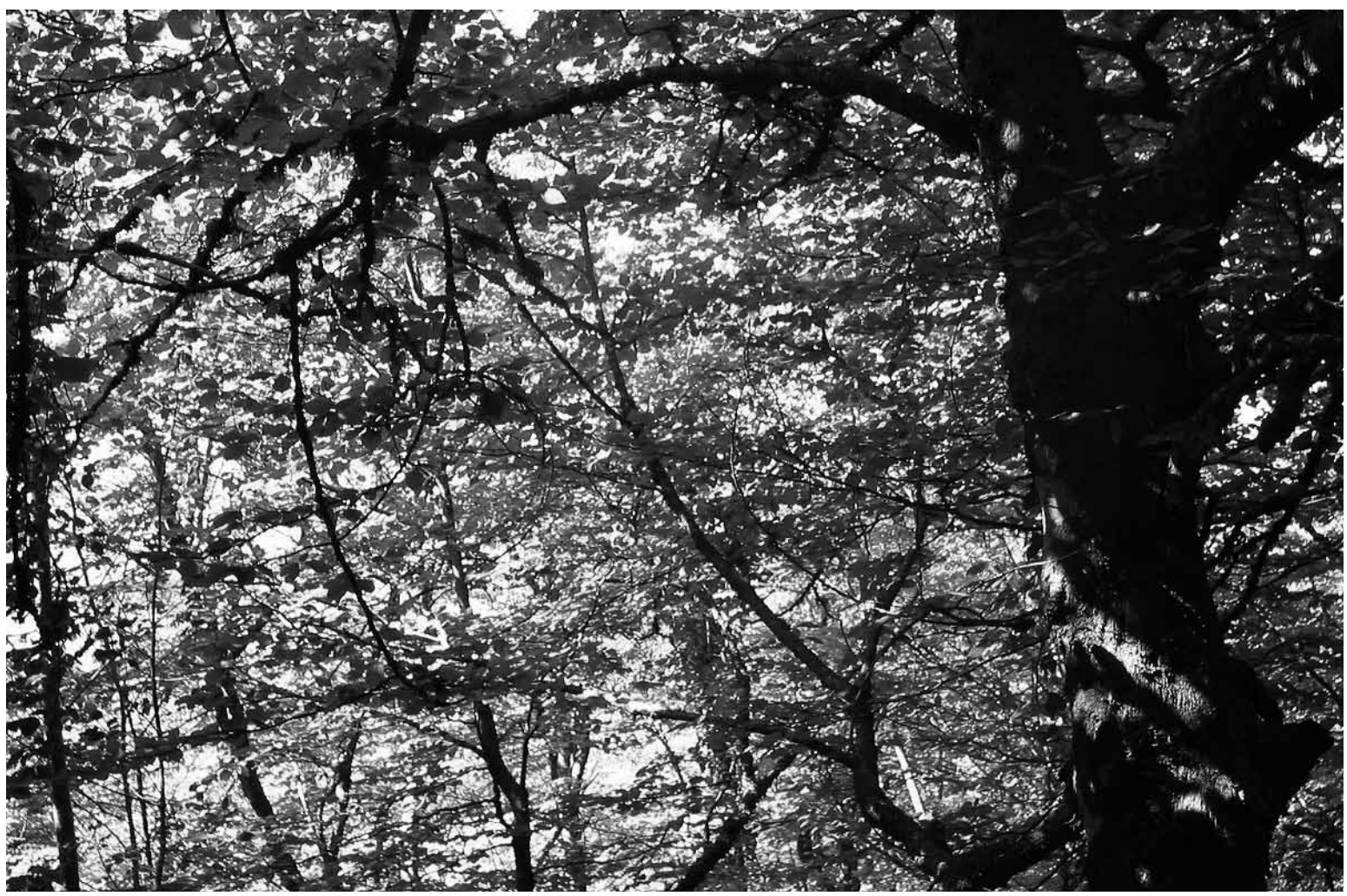


Claster analysis of proviniencies per leght, mass and mass of dry substance of the seed

Complete Linkage / Euclidean distances

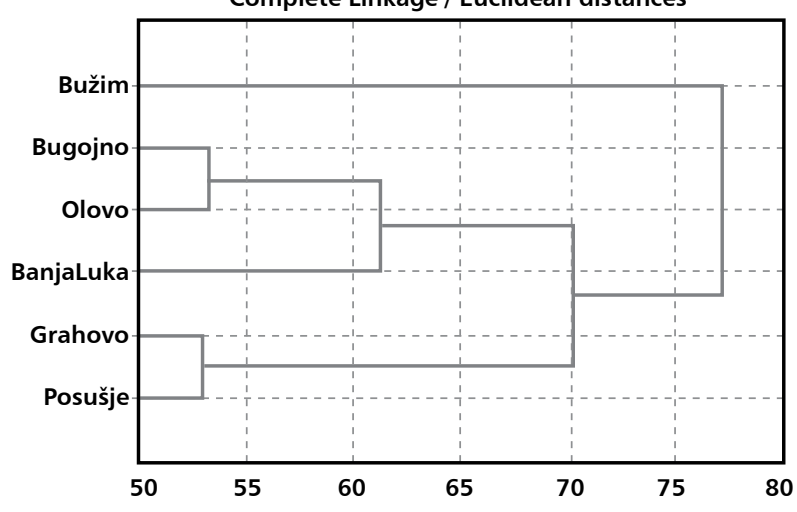

Figure 7

Dendrogram of cluster analyses made based on the measured data on length, width, mass and mass of dry substance of the seed of the analyzed proveniences. are grouped at the smallest genetic distance, and at Great distance on the other hand are Bugojno and Olovo (Figure 7).

The provenience of Banja Luka is between these two very close groups, which is more similar, due to smaller genetic distance, to the group of proveniences from Bugojno and Olovo. Proveniences Grahovo and Posušje together with previously mentioned three proveniences in one wider range make the group which is altogether very distant from provenience Bužim. It means that the researched proveniences show two, genetically very distant groups with expressed diversity obtained by measurement of morphological-metric parameters.

Grouping of proveniences in cluster-analysis can also be explained by its geographic position where more or less expressed even climatic conditions in Grahovo and in Posušje prevail, and moderate variant of these factors are Bugojno and Olovo. As we have already stated, the highest genetic diversity is recorded at beech from Bužim, which for sure can be attributed to particular territorial isolation from the impact of other proveniences.

\section{REFERENCES}

1. KAJBA D 2003 unutarpopulacijska i međupopulacijska varijabilnosto obične bukve. In: Matić S (ed.) Obična bukva (Fagus sylvatica L.) u Hrvatskoj. Akademija šumarskih znanosti, Zagreb, p 247-255

2. STOJANOVIĆ L, KRSTIĆ M 2005 Gajenje bukovih šuma. In: Bukva (Fagus moesiaca /Domin, Mally/ Czeczott.) u Srbiji. Udruženje šumarskih inženjera $i$ tehničara Srbije i Šumarski fakultet Univerziteta u Beogradu, Beograd

3. KLEPAC D, LUKIĆ $N$, GALIĆ Ž, božić $m$, meštrović š, čavlović j 2003 Uređivanje bukovih šuma. In: Matić $S$ (ed.) Obična bukva (Fagus sylvatica L.) u Hrvatskoj. Akademija šumarskih znanosti, Zagreb, $p$ 443-530

4. MATIĆ V, DRINIĆ P, STEFANOVIĆ V, ĆIRIĆ M 1971 Stanje šuma u SR Bosni i Hercegovini prema inventuri na velikim površinama u 1964 - 1968. godine. Šumarski fakultet Univerziteta u Sarajevu i Institut za šumarstvo, Posebna izdanja 7: 144-173

5. PINTARIĆ K 2002 Problem prevođenja izdanačkih šuma bukve (Fagus sylvatica L.) u visoku šumu. Šum list 126 (3-4): 119-128

6. VIŠNJIĆ Ć, MEKIĆ F, VOJNIKOVIĆ S, BALIĆ B, IVOJEVIĆ S 2009 Analiza stanišnih uslova i optimiranje uzgojnih mjera u panjači bukve na lokalitetu "Musići" kod Sarajeva. Radovi Šumarskog fakulteta Univerziteta u Sarajevu 1: 63-83

7. ROTH V, DUBRAVAC T, PILAŠ I, OCVIREK M 2005 Prilog poznavanju rasadničke proizvodnje obične bukve (Fagus sylvatica L.). Rad Šumar inst 40 (2): 207-214
8. GRADEČKI M, POŠTENJAK K, LITTVAY T 2003 Neke morfološke i fiziološke značajke sjemena bukve. In: Besendorfer V, Kopjar N (ed) 8. hrvatski biološki kongres s međunarodnim sudjelovanjem, Hrvatsko biološko društvo 1885, Zagreb, p 196-197

9. MATIĆ S, ORŠANIĆ M, ORLIĆ S, ANIĆ M 2001 Sjemenarstvo, rasadnička proizvodnja i šumske kulture obične jele (Abies alba Mill.). In: Prpić $B$ (ed) Obična jela u Hrvatskoj, Akademija šumarskih znanosti, Zagreb, p 375-393

10. ŠMELKOVA L 1969 Zakladanie lesa. Tehnicka univerzita vo Zvolen, Zvolen, p 239

11. STILINOVIĆ S 1985 Semenarstvo šumskog i ukrasnog drveća i žbunja. Šumarski fakultet Beograd, Beograd, p 399

12. ŠIJAČIĆ-NIKOLIĆ M, IVETIĆ V, KNEŽEVIĆ $R$, MILOVANOVIĆ J 2007. Analiza svojstava semena $i$ klijavaca različitih provenijencija brdske bukve. Acta biologica iugoslavica - serija G: Acta herbologica, 16(1):15-27

13. REYMENT R A 1985 Multivariate Morphometrics and Analysis of Shape. Math Geol 17 (6):

591-609

14. KREMER D, KARLOVIĆ K, JURIŠIĆ-GRUBEŠIĆ R 2008 Sezonska varijabilnost ploda i sjemena širokolisne veprine (Ruscus hypoglossum L.). Sjemenarstvo 25 (3-4): 193-205

15. ISAJEV V, MANČIĆ A 2001 Šumsko semenarstvo. Šumarski fakultet Banja Luka, Šumarski fakultet Beograd, Banja Luka, Beograd, p 280 